\title{
Architecture, space and power in historical multi-ethnic city Gresik
}

\author{
Dian Ariestadi ${ }^{1,2, *}$, Antariksa $^{3}$, Lisa Dwi Wulandari ${ }^{3}$, and Surjono ${ }^{4}$ \\ ${ }^{1}$ Civil Engineering, Faculty of Engineering Universitas Brawijaya, 65145 Malang, Indonesia \\ ${ }^{2}$ Civil Engineering, Universitas Negeri Malang, 65145 Malang, Indonesia \\ ${ }^{3}$ Architecture Department, Faculty of Engineering Universitas Brawijaya, 65145 Malang, Indonesia \\ ${ }^{4}$ Urban and Regional Planning, Faculty of Engineering Universitas Brawijaya, 65145 Malang, Indonesia
}

\begin{abstract}
The study of historical-morphology cities is conducted to discover the socio-cultural characteristics which influence the formation and development of spatial patterns and architecture. Gresik as the historical multi-ethnic city on the north coast of East Java, is known as a major trading port, the center spread of the Islamic religion, and the government city in the colonial era. This research has been made to know the morphological phenomenon of the historical city, by using a qualitative method. The result has shown: 1) the urban structure with the segregation of settlements based on ethnicity indicates the authority power to control its territory, 2) the building form which is dominated by colonial architecture shows the authority power to control the physical changes, 3) the courtyard-house concept which is widely applied in Kampung Arab indicates about the ethnic power to arrange the environment, and 4) the use of landhuis type and luxury mansions in Kampong Kemasan represents the power of successful people as government officials and entrepreneur. The spatial patterns and architecture of the historical multi-ethnic city - Gresik were influenced by the power aspects in the form of efforts to dominate each other and self-defense in the personal and communal levels.
\end{abstract}

\section{Introduction}

Until the 1960s era, the learning of architectural theories in many topics related to originality, harmonious composition, and associated with the happened phenomena. In the 1970s era, Alexander Tzonis and Manfredo Tafuri introduced a theoretical framework which linked between architecture and the socioeconomic-political contexts. Furthermore, Focoult, which is known as poststructuralist paradigm, explained how the expert knowledge affected the power of social working, and thus how the certain architectural configurations can play a role of disciplining people's minds and bodies. Based on Foucault's studies, many scholars conducted various studies about the diversity of architectural and social interaction patterns [1].

Currently, the development of a new theory of architecture studies is conducted to find more holistic relation using a variety of new paradigms including postcolonial. Postcolonial was originated from the emergence of movements against the colonialism paradigm, and the goal was toward the colonialism impacts in knowledge included the culture which influences individuals to dominate others. The concern could encourage increasingly chaotic world order. Postcolonialism is also oriented toward the realization of a new world relationship in the future. Postcolonial perspectives espouse a transformative agenda of architecture and urbanism that enables and empowers multiplicity in the processes of material production, the practices of their inhabitation, and the structures of representation. The attempt to break free of colonial hierarchies includes investigating the colonial dimensions of concepts like modernism, postmodernism, tradition, heritage, and sustainability. The interrogation of different demands for an investigation into the origins of the conceptual frameworks and spatial categories defines the discipline. Therein lies our future - and our hope - for a more just and equitable world which demands the globalizing knowledge production in architecture and planning [2].

The Development of Architecture and cities in Indonesia have been considering the historical development of coastal cities, especially in the north coast of Java. The cities in the north coast of Java are the trajectory of world trading and the spread of Islam. Gresik as one of the cities in the northern coastal region of East Java has a port and a major trading area, so that is where the influx of migrant ethnics of Chinese, Arabic and Dutch [3]. In general, the coastal cities evolved through the phenomenon of ethnic settlements as an important part of the formation of neighbourhood, city, and architecture. The city formed the heterogeneous multi-ethnic settlement with the close layout each other, and the power of space and architecture will affect the patterns of formation and development. In the northern

\footnotetext{
Corresponding author: dian.ariestadi.ft@um.ac.id
} 
coastal town of Java, there have formed the cultural characteristics of the coast, including space and architecture through a process of acculturation between Javanese culture and immigrant ethnic cultures or among the migrant cultures. The development of cities in the colonial era indicates the presence of political domination and power on the physical and cultural development of cities.

Political system and power can be concluded to have a good relationship directly or indirectly with the expression of architecture or the built environment. Moreover, the power is seen as the dominant factor determining the processes of social and cultural transactions between the roles of state on the one hand and the participation of people on the other side [4]. The control and maintain about the pattern of domination mastery become important to look at the characteristics of space and environment, particularly the establishment and development of city. The space and architecture pattern power and the patterns which maintain the dominance of power are essential to obtain the characteristics of space and environment in the processes of formation and development of city.

\section{Methodology}

The study has used the typology analysis through the qualitative description of spatial and architectural in cases of the building and the area [5]. The study has also used a qualitative approach with the consideration that the study is related to the historical region generally linked with the socio-cultural values that have the heterogeneous meaning and value and the symbol meanings which are the metaphorical tradition. Qualitative methods can be used to uncover the background of the socio-cultural-historical that is hidden behind the physical appearance of space, building and environment. Through in-depth interviews, this study repeated cross and would be disclosed what, why and how the background of the socio-cultural-historical observed objects [6].

The first step is the study of typology which conducted the exploratory of spatial patterns of residential environment and buildings in the area. The used data have been taken through the image map of area with transformed into a line mapping which shows the boundaries of building and environmental components. Typological analysis can be defined as a way to describe architecture in relation to its physical conditions by means of descriptive categories not dependent on "idealist" concepts of style and character [7].

The second step is to determine the study object in the form of case studies of spaces and buildings in Kampung Arab, Kampung Belanda, and Kampong Kemasan Gresik. Case studies will illustrate the historical development, the physical condition of the building and the environment, and other aspects of the socio-cultural-political accompaniments.

The final step is a qualitative in the depth descriptions of the study cases to find local concepts. Qualitative descriptions have been based on the data observations, interviews, and a comparison reference and theory. Researchers will make a complete illustration, researching archives textual, detailed reports from the perspective of the respondents, and conducted a study on the natural situation [8].

\section{Results and discussion}

\subsection{The old town Gresik typologies as historical multi-ethnic city}

Spatial typology at the old town of Gresik is dominated by the main functions of settlements, and some additional functions for trading facility, small office, and home industry. The existence of these functions was spread evenly across the Old Town area of Gresik. The old residential area in Gresik city consisted of: (1) Kampung Pecinan, the region which has the main function as a Chinese ethnic dwelling, (2) Kampung Arab, which is the region with the main function as a dwelling of Arab ethnic, with a pattern of enclosed settlement, and the activities of weaving craftsmen, (3) Kampong Kemasan, the region with the main function as a dwelling of Javanese ethnic with the strong ties of kinship patterns, and generally, it has a high socioeconomic level, (4) Kampung Kepatihan, as the region which has the main function as a dwelling for the government employees, and (5) Kampung Pakelingan, an area with residential function, and characteristics of merchants community [9]. Multi Ethnic Settlement in The Old City of Gresik is shown in Figure 1.

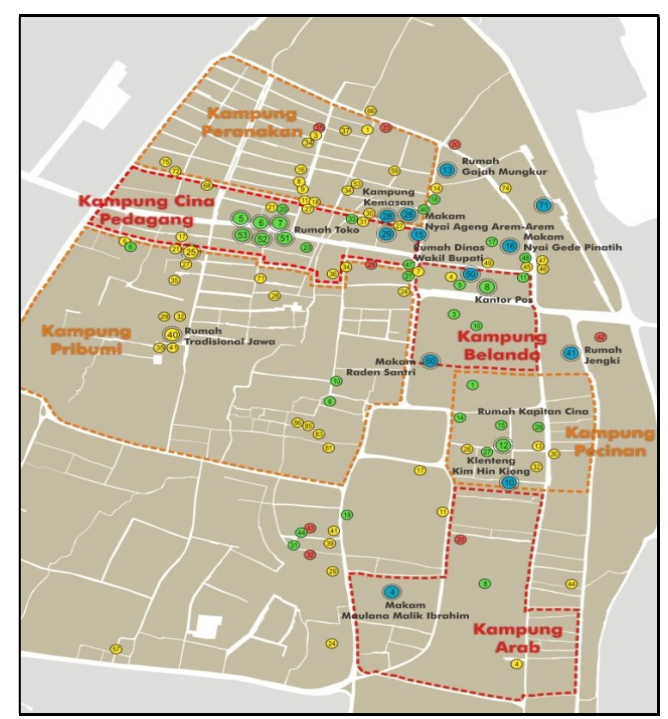

Fig. 1. Multi Ethnic Settlement in the Old City of Gresik (Source: The Green Map of Cultural Heritage Gresik, 2010).

The historical development of Java's cities relates to the historical development of trading cities in the northern coast of Java which was the entrance of cultures from outside. Several cities in the north coast of Java Island which have evolved since 1400 and earlier include Bintara, Jepara, Kudus, Lasem Tuban, Sedayu, Gresik, 
Surabaya, Baremi, Gending, Panjarakan, Binor, Ketah, Patukangan, and Blambangan [10].

Based on the development of towns in the north coast region, which was recorded as a trading city and major port city is Gresik, Tuban, Lasem, Semarang, Cirebon, and Batavia. The trading port city is an initial entry of foreign migrants to trade and settle. The Cities in the north coast of East Java, such as Lasem, Tuban and Gresik are the cities which had a port which served as a trading city, so that the Chinese, Arabic and Dutch came through VOC in 1602 [11].

Gresik actually has developed long before the colonialism era in Indonesia. The historical development of Gresik town was divided into phases: (1) Phase I, the period of 1480-1487, (2) Phase II, the period of 14871605, (3) Phase III, the period of 1605-1748, (4) Phase IV, the period of 1748-1916, and (5) Phase V, the period of 1916-2008. The establishment and development of the city started from the establishment of the kingdom of Giri Kedaton stages which evolved as a religious center, was dominated by the colonial Dutch and grew rapidly as the industrial and trading port city, attracted many immigrants from various ethnics and shaped the city with a multi-ethnic neighbourhoods in the old town area of Gresik [12]. The old city of Gresik is shown in Figure 2.

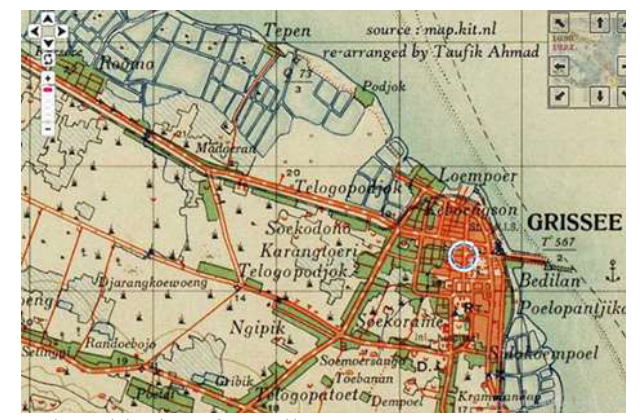

Fig. 2. The Old City of Gresik

(Source:http://www.semboyan35.com/printthread.php?tid=53\& page $=6$ ).

In the Dutch colonialism era, Gresik was a Afdeling region, which consisted of Gresik (the capital of residency), Lamongan, and the Sedayu district. The status was as an Afdeling only lasted until 1934, when it changed its status to be onderafdeling Gresik equivalent with Kawedanan. The port construction in Surabaya city in 1911 affected the trading track gradually moving to Tanjung Perak, and finally the merchants left the Gresik port. As a result, the Old Town of Gresik started to be abandoned. Thenceforth, trading activity in the area was more live during the day.

Gresik has a multi-ethnic settlement in the adjacent region to shape the character of specific environment. Gresik city structure formed from multi-ethnic settlements adjacent specific and can still be observed today. Heterogeneous structure composed by multiethnic enclave settlements, with a colonial style building that stands out, and the formation of open spaces in the middle of building homes and neighborhoods in Arab and China settlement. The multi-ethnic settlements of Gresik was formed and developed in the geographical environment and culture of the north coast of Java, in the colonialism era in Indonesia.

\subsubsection{Landhuis typology in the old town of Gresik}

The architectural style of existing buildings in all multiethnic settlement in the old city of Gresik is a colonial style. The condition was caused due to the development of Gresik town as a port city with many ethnic immigrants which began in the 1605-1748 period and rapidly grew in the 1748-1916 period. The architectural building style of region is dominated by the colonialstyle which is shown in Figure 3.
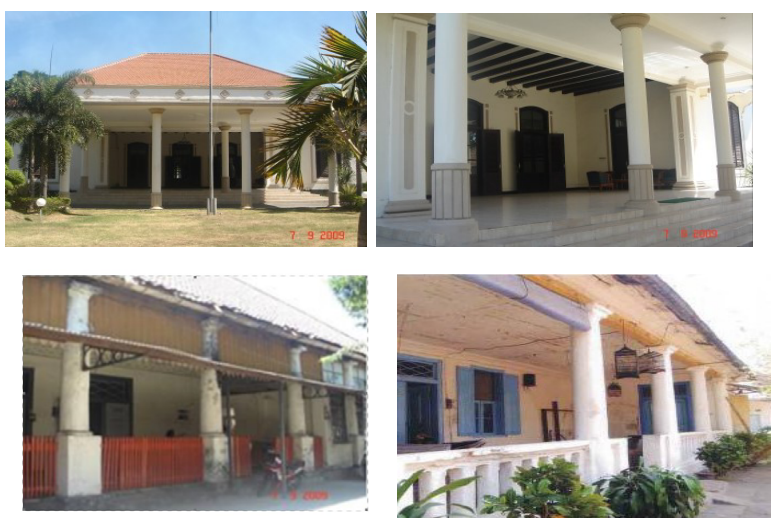

Fig. 3. The typology of Colonial-style Building in Gresik (Source: The Green Map of Cultural Heritage Gresik, 2010).

The formation and development of the physical condition of Gresik town, as seen in the old city area nowadays mainly occurred in the 1748-1916 period and were marked by the growth of industrial and trading activities in Kampung Kemasan. This era included the 1800-1902 period which represented the period of Indonesia architecture development. The period was marked by the dissolution of VOC and the takeover of the Dutch East Indies by the Kingdom of the Netherlands.

The architectural style which was widely used is referred to as Neo-Classical, in the form of a classic style reapplied using a new material. The buildings which were built in this period are often referred to as the Empire Style. Building typologies in this architectural style have considered about the climate context in the design process. Building typologies that are typical such a symmetrical floor plan and a solid, thick and massive wall. The specific characteristics of colonial building in Indonesia include: (1) having arcades surround the outside spaces serve as a connecting line, and for thermal insulation and sunlight; (2) large roof with the steep slopes, sometimes comprising two layers with gaps for transferring heat or air, (3) high ceiling to avoid the heat on the room, (4) wall with large windows, (5) the size of windows and doors are large and high, and (6) the thick wall-room to reduce solar heat [13-14].

Furthermore, the colonial cultures interacted with local culture or acculturation, and established a new culture called Indies culture. The characteristics of Indies culture in Indonesia can be traced in: languages (pizjin), clothing (native king), home furnishings (furniture), and 
residential buildings (landhuis). Indies architecture is a style of architecture which blended between European architecture and local architecture to adapt the climate in Indonesia (tropical climates). The building characteristics of architectural Indies, including landhuis are: the high slope of roof to enlarge the volume of space under the roof, the high ceilings, vents in the top of doors and windows (fanlight or bovenlicht) perforated (ventilation block or krawangan); the front and back porches, located slightly to inside (the influence of Javanese house), and the attachment of natural stone plates in outside the bottom of buildings [15].

In the era of colonialism, the development of urban space and building structure governed by the laws of strict colonial rule. This shows the power of the colonial government in controlling the physical development of the region is very strong. There are two ages have great influence on morphological development of cities in Java, namely: 1) after 'Java Oorlog' / Java War in 18251830, followed by the system Cultivation (Cultuurstelsel), and 2) after the implementation of the Law of sugar 'in 1870 and the Law of Decentralization in 1905 [16].

As a political form of multi-ethnic and multi-culture, the colonial government developed the 'area of governance' (political domain) and 'trading area' (economical domain) [3]. Many wealthy people as a result of trade in coastal cities appointed rulers in the region. Furthermore, the environmental authorities have adopted a building officials and environmental conditions. The use of this building typology benefit from the government as a form of hegemony, and for society as a form of socio-economic success [17]

The characteristics of space and architecture in the area are dominated by the physical form of colonial architecture building which shows the dominance by the Dutch colonial government as an extremely strong power determinant. The building characteristics of official houses of landhuis types which are located in the Dutch settlement indicate an attempt to give the domination of spatial and architectural environment in the Old City of Gresik.

\subsubsection{Courtyard in Kampung Arab Gresik}

The existence of Kampung Arab Gresik that has been from the $1600 \mathrm{~s}$ era, the patterns of residential and region were formed and developed in the colonial trading era, and survived until nowadays, influencing and forming the specific cultural community in Gresik today. Kampung Arab Gresik area is closed by the ethnic settlements and forms a Ethnic enclave pattern. The existence of ethnic enclave in this region is a picture of multiculturalism and diversity which can be used to maintain an ethnic culture, such as cultural activity and language [18].

Residential unit area in the center of Kampung Arab region, in general, is residential houses with a large area. The shape pattern of residential areas is a Cul de sac, with one access for entry and exit as shown in Figure 4. Generally, the dwelling has a front yard that serves as a receiving area after the main gate. The typology of courtyard building forms is located behind the main house. Furthermore, there are differences that separate the guest access to male and female guests. The access of male guests (public) is towards the main building, and the access of female guests (private) moves toward the courtyard space. The front yard can serve the private activity when the main gate is closed as shown in Figure 4.
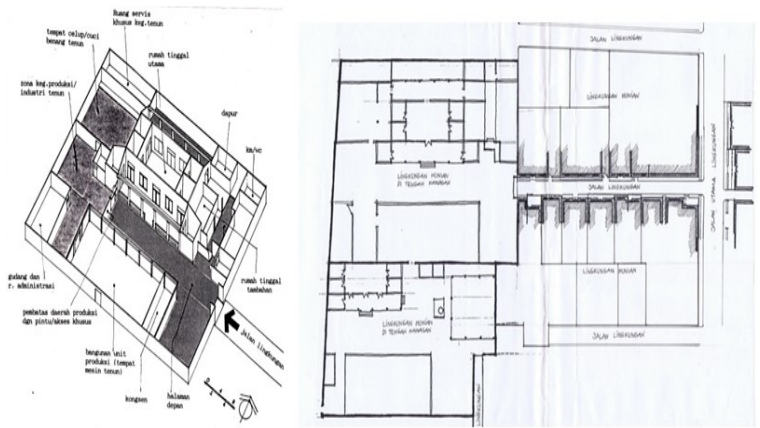

Fig. 4. Courtyard housing in the center area of Kampung Arab (Source: D. Ariestadi, 1999).

While the dwelling units in the road edge, both of the environment and the main street are a smaller residential area. In general, residential building has a boundary with the road environment, the main street of the area, or other dwellings. This building only serves as a dwelling house without the additional function of business activity. Courtyard space is located in the back or side, with separate access (entrance side). Thus, there are always two accesses namely the main access and the additional access which is marked by a door covered by a curtain or 'kerai'. Side entrance is located in the building edge, or, due to the limited of wide building, it can be located in the different street as shown in Figure 5.
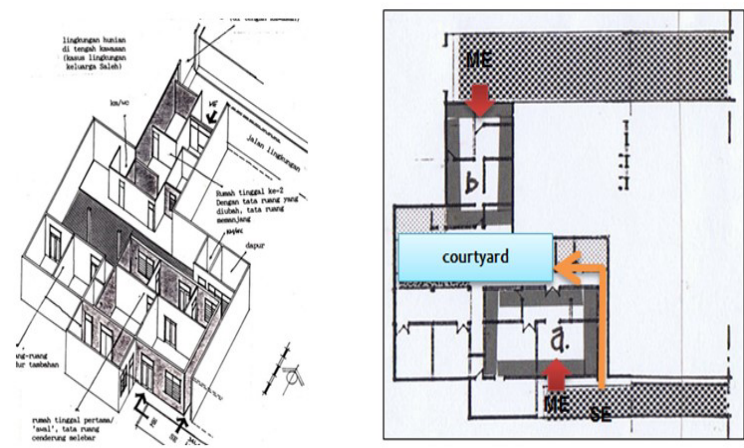

Fig. 5. Courtyard housing in the edge area of Kampung Arab (Source: D. Ariestadi, 1999).

Characteristics of courtyard houses in the ArabIslamic architectural typology aim to meet the needs of protection level of the occupant privacy, particularly women in interaction with outsiders and male visitors, how to serve guests, attitude and responsibility towards the neighbours, and simplicity in life [19-21]. The typology of courtyard houses is related with the religious culture aspects, especially regarding to the privacy and 
separation activities, and visual access between men and women [22]. In traditional Islamic or Arab culture, it is important to separate men and women to protect the house against outsiders. The houses were designed to create a separate physical space between men and women, as well as to prevent the visual contact.

Courtyard house typologies in 'Kampung Arab' Gresik formed through a process of cultural adaptation by occupants in different settings. Courtyard house concept used in accordance with the demands of the inhabitants of the territory of gender space, privacy, and comfort. Environmental spatial patterns are formed in urban enclave settlements with the concept courtyard can arrange access system that supports the principle of the separation area of gender and privacy, as well as very efficient to control environmental thermal comfort. Nevertheless, the presence of the use of courtyard house concept which stands out in the residential neighborhood in Arab ethnic indicated the efforts to realize the domination power of strong ethnic in their own environment.

\subsubsection{Luxury mansions in Kampong Kemasan Gresik}

Kampung Kemasan is one of the alleys located in the old town area of Gresik. Historically, this village is called 'Kemasan' for its inhabitants work mostly gold handicraft makers. Currently, the craft of making gold was no longer found in this alley. Homeowner in this village are successful entrepreneurs, thus they built the unique and interesting house.

In general, residential buildings in Kampong Kemasan Gresik are composed of two building masses, which function the main building as the main activity for homeowners and the additional building as birds' nest. Two masses of the building are separated by a courtyard. In addition, there is also a building wing which is functioned as a service area [12]. The main building is a dwelling house typology mansion consists of 24 buildings. Identification of the typology of the building style is Dutch Colonial building with neo-classical style with influences of Chinese architecture and Arabic. Characterize the influence of Chinese vernacular house in the form of two storey building. The upper floor is made without partitions and used for storage and livelihood activities. Characterize the influence of Arab culture is spatial indicate an attempt to distinguish the activities of women and men, through the use of bamboo curtain covering the activities inside.

The most interesting element of buildings is the number of doors and windows which are more than a residential home in general. In front of the house, there is a form of stealth window, the window shaped ornaments which include the ventilation holes on it, but in reality the window deadlocked. The window was only made to decorate and beautify the building. In addition, the unique characteristics of residential buildings are also seen in the many ornaments in the buildings. The typology of residential buildings in Kampong Kemasan Gresik is shown in Figure 6 [23].
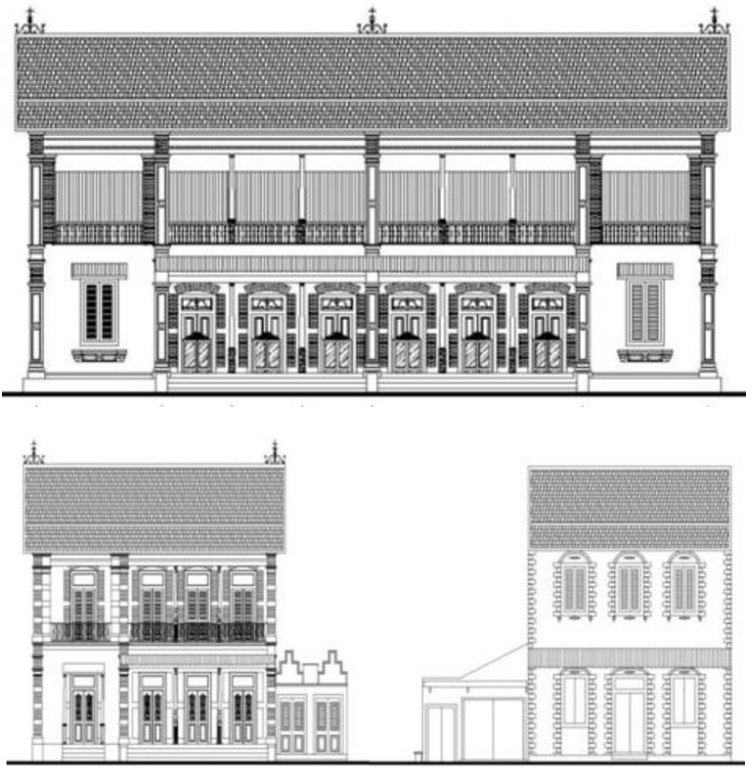

Fig. 6. Typology of residential buildings in Kampong Kemasan (Source: PU Ciptakarya Kabupaten Gresik, 2013).

The buildings and ornaments in residential houses in Kampong Kemasan were influenced by Chinese, Arab and European cultures. The Chinese influence is seen in the use of ornament to the wrought iron beams, which serves as the locking of doors and windows. The ornaments are generally found in Chinese style house. The Chinese influence is also shown in the dominance of use the red colour in the building. The red colour represents fire and blood which symbolize prosperity and luck, but red also is a symbol of virtue, truth and sincerity. The influence of Arabic culture is seen in: (a) the existence of patterned brick ornamentation in the pillars or columns and walls both exterior and interior building, with a triangular arrangement or pyramid, in which the composition of multiples-three, identic with the mosque roof; (2) the use of ornaments with the crenellation or Merlons motif is often found in the religious building ornaments; and (3) The use of the natural shape is the stylized-plant elements (flowers, leaves and branches). Floral motifs have been a medium of decorative expression due to the religious understanding of Islam that prohibits painting or creating the soulless creature sculptures, especially those can move or walk. The European cultural influences are seen in the peak of the roof ornaments, gevel and geveltoppen [13].

Building on the corridor Kampung Kemasan tend to have a colonial style and another in part Chinese-style architecture [12,23]. Dutch architectural style of the building is established earlier, because at the time there was no other building models that describe greatness and luxury. In the postcolonial perspective, the embodiment of the symbols indicate desire to showcase identity and the ability to live / to strugle of a group of sub-altern. The dynamics of the understanding and use of the building typology of luxury in Kampong Kemasan Old City Gresik is influenced by: 1) political power, in this case all the artifacts colonialism as a symbol of power, 
2) attempts to show identity as minority groups were successful, and 3) efforts resilience to retains its identity [2].

The characteristics of the luxury building houses of a successful entrepreneur in Kampong Kemasan indicate an attempt to give the domination of spatial and architectural environment in the Old City of Gresik. The used ornaments were manifested with clear, very attractive, dominating, and even those are extremely interesting in its environment. The ornaments have also the symbols and meanings of success, prosperity, and positive values including virtue, truth and sincerity. Thereby, the existence of homeowner as a successful entrepreneur will gain prominence in the community.

\subsection{Space and power in historical multi-ethnic city Gresik}

Establishment of space and architecture in the multiethnic city of Gresik historically strongly influenced the dynamics of politics and power. Spatial and environmental building is based on a strong Islamic culture show the role of Islamic government as the initial formation of the town of Gresik. Spatial heterogeneous multi-ethnic describe government policy is the kingdom until the colonial government set Gresik city as a port city and growing as a center of commerce and government in the eastern region of the island of Java. While the physical dominance of colonial building with architectural influences show the strength of colonial government that controlled the region in the long term.

An overview of the formation of space and architecture shows that studies about architecture and multi-ethnic city is mostly conducted to find the concept of formation and use of spaces, because of the presence of complex interaction of diverse aspects including social, culture, and politic. This is in accordance with the theory of 'Production of Space' that emphasize social interaction as an important aspect in the formation of space [24], and the theory of 'Power of Place' which states that the use of space in the area of multi-ethnic influenced by aspects of domination and control of user groups space [25].

Postcolonial paradigm will be disclosed through the perspective of the opposing party (sub-altern). The dominance of power political forces that shape the space and architecture is balanced by the power-ethnic society as a user who wants to be able to control the social and cultural needs including space and architecture. The dynamics of space adjustment and colonial architecture with ethnic Chinese and Arabic influences shaping acculturation specific space and architecture, as seen through landhuis colonial building typologies in the entire area of the old town, courtyard houses pattern in Kampung Arab and luxury mansion in Kampung Kemasan. In the government that controls the political pressure, the adjustment of space and architecture in an effort to preserve the identity, privacy, and existence itself.

Space and built environment are instruments that reinforce hierarchies and the negotiation of relations of differences and adjustments. Postcolonial can show more unique ways and particles of forms and histories on the scope of global interconnection; henceforth considered to be universal, as well as the European modernism, which actually is a fact on the scope of provinces and particles [26]. Postcolonial thinking can contribute to the interpretation of architecture and city as a cultural artefact and as a symbolic landscape formed from the layers of meaning and identity. Postcolonial perspective can describe the political influence in architecture and urban governance [27].

\section{Conclusion}

The cities in Indonesia which developed in the colonial era greatly were influenced by the dominance of colonial government about the formation and development of the city physical character. The specific condition of environment and residential patterns in the old town of Gresik is the existence of multi-ethnic enclave settlement. The characteristics of space and architecture in the area were dominated by the physical form of colonial architecture building which showed the dominance of Dutch colonial government as an extremely strong power determinant. Nevertheless, the presence of the use of the courtyard-house concept which was applied in the ethnic Arab settlement indicates the efforts to realize the power of strong ethnic domination in their own environment. The characteristics of the house-officials of landhuis types which is located in the Dutch settlement, or a luxury mansion building of successful entrepreneur houses in Kampong Kemasan also indicates an attempt to give the domination of spatial and architectural environment in the Old City of Gresik. There is an attempt to establish the mutual power of space and architecture that will always occur in the establishment and development of space and the environment, while on the other hand, attempt to maintain the domination of power will always happen.

\section{References}

1. H. Heynen, G. The book of Architectural Theory. SAGE Publications Ltd. (2012)

2. J. Hosagrahar. The book of Architectural Theory. SAGE Publications Ltd. (2012)

3. R. Damayanti, Handinoto. Dimensi Teknik Arsitektur. 33, No. 1 July (2005)

4. M. S. Barliana, http://file.upi.edu/Direktori/ FPTK/JUR. PEND._TEKNIK_ARSITEKTUR/196 302041031 MOKHAMAD_SYAOM_BARLIANA/ Articles Makalah_Ilmiah/ĀrsitekturKekuasaan.pdf. Accessed, 10 October 2015

5. L. Groat, D. Wang. Architectural Research Methods. John Wiley \& Sons, Inc. (2002)

6. G. E. Guba, S. Y. Lincoln. Naturalistic Inquiry. Beverly Hills: Sage Publications Inc. (1985)

7. A. Salama, METU JFA. 1, 23: 1 (2006) 
8. J. W. Cresswell. Qualitative Inquiry \& Research Design, Choosing Among Five Approaches. SAGE Publications Ltd. (2007)

9. A.A.S.I. Widyastuty. Jurnal Teknik WAKTU. Vol. 09, No. 02 (2011)

10. Sudaryono. Laporan Jurnalistik Kompas. 2008

11. B. Fauzy, Antariksa, P. Salura, DIMENSI. Vol. 38, No. 2 (2011)

12. C. Riski, Antariksa, Surjono. Arsitektur e-Journal. 2 Nomor 2 (2009)

13. Y. Sumalyo. Gadjah Mada University Press. (1993)

14. Handinoto. Perkembangan Kota dan Arsitektur Kolonial Belanda di Surabaya 1870-1940. Penerbit Andi. (1996)

15. J. Soekiman. Komunitas Bambu. (2014)

16. Handinoto, Dimensi Teknik Arsitektur. Vol. 32, No. 1. (2004)

17. D. Ariestadi. Jurnal Teknologi dan Kejuruan. FT UM. (1999)

18. S. Mazumdar, EDRA 36-2005. (2010)
19. A. Shorbagy. IJCEE-IJENS. 10 No: 04. (2010)

20. F. A. Mustafa, A. S. Hassan. American J. of Engineering and Applied Sciences, 3 (2010)

21. A.Z. Karimi, B. Hosseini. Proceedings: ArchiCultural Translations through the Silk Road 2nd International Conference, Mukogawa Women's Univ., Nishinomiya, Japan, July 14-16. (2012)

22. N. Qomariyyah, Antariksa, E. Y. Titisari. Arsitektur e-Journal. 2, Nomor 2, Juli (2009) 79-89

23. PU Ciptakarya Kabupaten Gresik. Laporan Akhir Detail Pelaksanaan Tindak Konservasi Kawasan J1. H.O.S. Cokroaminoto- J1. Nyi Ageng Arem-Arem. (2013)

24. H. Lefebvre. Book of Rethinking Architecture: A Reader in Cultural Theory. Routledge (1997)

25. D. Hayden. The MIT Pres, (1995)

26. E. Akcan. SAGE Publications Ltd. (2014)

27. A. Kusno. Behind the Postcolonial Architecture, urban space and political cultures in Indonesia. Routledge. (2000) 